\title{
Well-being of unemployed people: relations with work values and time of unemployment
}

\author{
Bem-estar de pessoas desempregadas: relações com \\ valor do trabalho e tempo de desemprego
}

\author{
Ariana FIDELIS ${ }^{1}$ iD 0000-0003-1410-6132 \\ Helenides MENDONÇA ${ }^{1}$ iD 0000-0003-3990-5432
}

\begin{abstract}
This study aims to analyze the moderating power of time of unemployment in the relationship between work values and psychological well-being. The sample consisted of 265 unemployed individuals, 77 men and 188 women with an average age of 27 years $(S D=7.21$ ), with complete secondary education in $48 \%$ of the total sample. The following data collection instruments were applied: Positive and Negative Affect Schedule, the Flourishing Scale and the Work Intrinsic Values Scale. The results of hierarchical regression analyses show that time of unemployment acts as a moderator in the relationship between the work values and the psychological well-being, so that the longer the unemployment duration the greater the individual's psychological well-being. Consequently, the shorter the period of unemployment, more intense is the feeling of negative emotions. The result yield three important contributions: demonstration of the association between work values and psychological well-being of unemployed; identification that the period of unemployment is an important moderator to understand the unemployed well-being and review of the issue of unemployment in the social and political field in times of recession.
\end{abstract}

Keywords: Job; Moderation; Positive Psychology; Unemployment.

\section{Resumo}

O presente estudo tem como objetivo analisar o poder moderacional do tempo de desemprego na relação entre o valor do trabalho e o bem-estar psicológico. A amostra foi composta por 265 desempregados, sendo 77 homens e 188

$\Delta \nabla v$

1 Pontifícia Universidade Católica de Goiás, Escola de Ciências Sociais e da Saúde, Departamento de Psicologia. Av. Universitária, 1440, Setor Universitário, 74605-010, Goiânia, GO, Brasil. Correspondence to: H. MENDONÇA. E-mails: <helenides@gmail.com>, <arianafidelis.a@gmail.com>.

Article based on the dissertation of A. FIDELIS, entitled "Significado do trabalho e o bem-estar psicológico: um estudo com desempregados". Pontifícia Universidade Católica de Goiás, 2016.

How to cite this article

Fidelis, A., \& Mendonça, H. (2021). Well-being of unemployed people: relations with work values and time of unemployment. Estudos de Psicologia (Campinas), 38, e190014. https://doi.org/10.1590/1982-0275202138e190014 
mulheres, com idade média de 27 anos ( $D P=7,21)$; destes, 48\% tinham Ensino Médio completo. Foram aplicados os seguintes instrumentos de coleta de dados: Escala de Afetos Positivos e Negativos, Escala de Florescimento e Escala de Valores Intrínsecos do Trabalho. Os resultados das análises de regressão hierárquica demonstram que a duração do desemprego atua como moderador na relação entre o valor do trabalho e o bem-estar psicológico, de modo que, quanto maior a duração do desemprego, maior é o bem-estar psicológico das pessoas. Consequentemente, quanto menor for a duração do desemprego, maior é a vivência de sentimentos negativos. Os resultados trazem três importantes contribuições: evidenciam haver associação entre valor do trabalho e bem-estar psicológico de desempregados; identificam que a duração do desemprego é um moderador relevante para compreender o bem-estar de desempregados; analisam questões relativas ao desemprego em tempos de recessão no campo social e político.

Palavras-chave: Trabalho; Moderação; Psicologia Positiva; Desemprego.

In general, the experience of unemployment is annoying, in addition to being a mechanism of a degrading social exclusion of contemporaries. It is considered as a side effect of globalization. In the globalized world, marked by social, economic and political problems, available workers without a job signal a rupture in social cohesion, and could become a serious threat to Western societies. Unemployment can cause serious damage in the individual and social spheres, since work is considered by many scholars as a source of mental, social and economic balance, as a source of health and well-being (Barros \& Moreira, 2015).

In recent years, it has been observed that events at the macro-social level, for example unemployment and its relationship with psychological variables, such as well-being have aroused greater interest in the social sciences. One of the reasons that explains this significant increase in studies on the subject is the fact that unemployment has one of the most devastating consequences on well-being, whether prolonged or not (Fryer, 2015; Parker, Jerrim, \& Anders, 2016).

For Barros and Moreira (2015), unemployment is debilitating and felt as a loss, which generates personal discouragement in the face of frustrations resulting from the failure to find a job, the financial difficulties, the image of the unemployed before family and friends, among others. In order to better understand this phenomenon, the present study conceives unemployment as an absence from work for more than 30 days, due to the lack of opportunities in the market.

Historically, unemployment is associated with a variety of harmful physical and psychological effects, such as increased alcohol consumption (Popovici \& French, 2013), heart disease (Lundin, Falkstedt, Lundberg, \& Hemmingsson, 2014), in the incidence of mental health problems, depression and other psychopathologies (Wanberg, Kanfer, Hamann, \& Zhang, 2016), low levels of self-esteem (Hergenrather, Zeglin, McGuire-Kuletz, \& Rhodes, 2015), psychological well-being and has a negative relationship when related to life satisfaction and happiness (Zhou, Zou, Woods, \& Wu, 2019).

Despite what was mentioned earlier, the relationship between well-being and unemployment is still poorly studied according to the literature. However, it is known that well-being is subject to the influence of several factors, such as marital status, age, financial resources, among others (Ferreira et al., 2015). Thus, according to Sage (2019), unemployment is one of the factors that also influences the diminishment of welloccur mainly due to the centrality and the role that work plays in people's lives.

For Dejours, Dessors, and Desriaux (1993) work brings meaning and significance to man's life, and it is through them that individuals are motivated and set out in search of their goals, in a dynamic relationship. In view of this strong relationship work is a historical product that is part of the construction and development of society with strong personal and social value. Besides, it is an important element that is part of the individuals built up identity and plays an expressive role in the economic and social setting (Gagné et al., 2015). Thus, in order to understand the impact of unemployment on the individual's life, one must consider the meaning and the value that individuals give to the work itself. 
According to the literature, the value of work refers to the attributions given by the individuals who socially translate their beliefs and needs in relation to work where values are trans-situational principles, organized hierarchically and subdivided into two categories: intrinsic and extrinsic (Schwartz, 1999). Intrinsic values of work are those behaviors oriented towards personal development, in an attempt to satisfy basic psychological needs such as autonomy, acceptance, among others. Extrinsic values are characterized as behaviors oriented by external conditions, such as status, appearance, power (van den Broeck, Vansteenkiste, Lens, \& Witte, 2010).

In view of these assumptions and the importance of work in society, considering the growing number of unemployed, we intended to investigate how much the value of work can help to face unemployment, allowing an increase in positive expectations, as well as providing excellent experiences, capable of restoring life balance and psychological well-being. Thus, the hypothesis is set that in view of the high perception of the intrinsic value of work, it is wise to adjust to unemployment hence stabilizing its harmful effects ( $\mathrm{H} 1)$.

Furthermore, no matter how frustrated and dissatisfied an individual is regarding his/her work, being employed is fundamental in the individuation process, since it is through work that the subject is driven to seek new results that enable him/her to feel pleasure and self-realization (Li, Wei, Ren, \& Di, 2015). For this reason, unemployment affects the psychological well-being of individuals, as it is able to deprive the person of the latent benefits: work structure, commitment, the meaning of work per se and also the manifest benefits: salary and fringe benefits (Huffman, Culbertson, Wayment, \& Irving, 2015; Trewick \& Muller, 2014).

When considering that the feeling of well-being can be modified over time due to the influences of contextual variables (Junça-Silva, Caetano, \& Lopes, 2016), unemployment appears as one of the elements capable of changing that feeling. However, despite the fact that unemployment negatively influences wellbeing, it is observed that these negative effects can be stabilized throughout the period without a job, as this is a phenomenon with macro-social dimensions; contextual variables such as the socioeconomic context, social security policies and capital opening, family support, informal work, among other factors can help cope with unemployment (Ahn \& Hamilton, 2019). For this reason, investigators have found that unemployed people may show signs of adaptation or habituation depending on how they face this period without a job (Pignault \& Houssemand, 2018).

This adaptation is considered by some authors to be the normalization of unemployment, which occurs when the individual is able to regulate his/her emotions in the face of the situation and gets to considers that event as normal or common. This self-regulation of cognitive processes helps to cope with stressful events and their deleterious effects (Pignault \& Houssemand, 2017, 2018).

It should be noted that some investigations have shown that in the first months without a job, the negative effects of unemployment are more pronounced, which requires the mobilization of positive dispositional characteristics of the individual such as optimism, the sense of purpose and meaning of life, coping strategies already mentioned, among others (Pignault \& Houssemand, 2018; Su, Tay, \& Diener, 2014; Thill, Houssemand, \& Pignault, 2019).

Despite this and other studies claiming that unemployment in general is a degrading experience, it is possible to see that the personal values linked to work and the way the individual perceives unemployment, associated with socioeconomic aspects and social security policies, can be predominant in the reduction of unrest during long periods of unemployment (Thill et al., 2019; Virkes, Serši , \& Lopez-Zafra, 2017). Such assumptions point to the influence of the socio-cultural and economic aspects necessary to face unemployment and its negative effects (Virkes et al., 2017).

In this sense, when considering that unemployment is impacted by multivariate demands, and that in the first months without a job the deterioration of psychological well-being is more pronounced, coping strategies can reduce this disturbance (Pignault \& Houssemand, 2018). It is believed that other factors such as 
the value of work, social support, optimism, identification with the task, protection policies, unemployment insurance, duration of unemployment can help coping with this situation and constitute a protection against the deterioration of well-being (Nekoei \& Weber, 2017; Sage, 2019). Based on these factors, it is assumed that unemployment negatively affects the psychological well-being of individuals, in the first few months without work, constituting the hypothesis $(\mathrm{H} 2)$ of this study.

Regarding the time of unemployment, it is seen in the literature that some people face the situation in a more positive way, self-regulating their emotions when they feel supported by family members. In addition, some individuals rely on incentives offered by the government through social security policies (Nekoei \& Weber, 2017; Thill et al., 2019).

According to Wanberg et al. (2016) in the first 6 months the perception of unemployment is more negative. Soon after, between 6 and 11 months, there is a certain fluctuation that leads to both a negative and positive perception about unemployment. After 12 months, a balance is observed, which indicates the normalization or stabilization of the harmful effects of unemployment. Thus, the gradual recovery of homeostasis is noticeable after periods of unemployment.

Other factors that help to restore the emotional balance and well-being during unemployment are social security plans and incentives for entrepreneurship. It is observed that people living in countries with social security policies and that encourage the creation of small businesses suffer less from the adverse effects of unemployment (Farber \& Valletta, 2015). This is the opposite of underdeveloped countries, where unemployed individuals stumble on funds scarcity, high cost of living, as well as little incentive to create small businesses and therefore tend to suffer more from the negative effects of unemployment (Duygan-Bump, Levkov, \& Montoriol-Garriga, 2015; Startiene \& Remeikiene, 2015).

Studies conducted in countries such as Norway and Finland show that unemployment does not have a negative correlation with psychological well-being, due to the benefits of unemployment insurance maintained by social security policies (Duygan-Bump et al., 2015). In the United States of America, this measure is also observed, since unemployment insurance policy benefits the unemployed workers by giving them the resources to qualify and reintegrate into the labor market (Black, Devereux, \& Salvanes, 2015).

As seen, the dispositional characteristics of cognitive self-regulation, associated with employment protection policies and unemployment insurance benefits, can make unemployment, especially long-term unemployment, less painful for people (Farber \& Valletta, 2015; Landais, 2015; Thill et al., 2019; Wanberg et al., 2016).

Another major factor to reduce the negative dissonance generated by unemployment is the engagement of the unemployed workers in the creation of their own business. For Startiene and Remeikiene (2015), job loss can sometimes act as an impulse that encourages people to start their own business. Some authors Duygan-Bump et al. (2015) and Startiene and Remeikiene (2015) claim that micro-enterprises and self-employment can become an alternative for reducing the number of unemployed people, as people find new job opportunities and a way to cope with stressful situations.

Considering the above, it is believed that the experience of negative affects experienced by the unemployed tends to stabilize over time, if coping is observed, together with the positive perception of work and its manifest value (Mousteri, Daly, \& Delaney, 2018; Thill et al., 2019). Therefore, based on these concepts, the hypothesis is established that the duration of unemployment acts as a moderator in the relationship between unemployment and psychological well-being $(\mathrm{H} 3)$. It is where the time of unemployment moderates the relationship between the value of work and well-being, so that the longer the time of unemployment, 4 the greater this relationship. 


\section{Method}

\section{Participants and Procedures}

The sample consisted of 260 individuals, unemployed for more than 30 days, aged 18 years or over, of both genders, from the city of Goiânia and the metropolitan region, Goiás state. Out of these, $72.9 \%$ were women with an average age of 27.32 years $S D(7.21)$, with a minimum age of 18 and a maximum of 57 years; $52.3 \%$ reported they were single; $48.4 \%$ stated they had completed high school. The average duration of unemployment was 7.26 months $S D$ (8.05), with a minimum of 1 month and a maximum of 36 months. With regard to the questionnaires 197 were filled in-person and 63 virtually. A $t$-test was performed to identify if there was a significant difference between the responses given personally or virtually and it was found that there were no differences in the answers given. Therefore, it was decided to review the data together.

\section{Instruments}

To perform the hypothesis test, the following measurement instruments were applied. The Work Values Scale was adapted and validated by Feather (1990). The original scale consists of a set of 14 Likerttype value items that respondents ranked from 1 (strongly disagree) to 7 (strongly agree). Such a scale assesses intrinsic and extrinsic values in relation to work. In order to verify whether the Work Values Scale was structured according to Feather's measurement (1990), exploratory and confirmatory factor analyses were performed. Items that did not have a factor load greater than 40, were excluded. In this study The Work Values Scale, was composed of 7 items that refer to the intrinsic values of work $(\alpha=0.78)$. Examples of items are: "Work is the most important thing in life", "I prefer a job with a lower salary than being unemployed".

To assess psychological well-being, the Flourishing Scale, originally developed and validated by Diener et al. (2009) and validated in Brazil by Mendonça, Caetano, Ferreira, Felix, and Junça (2014) was used. The Flourishing Scale in this work consisted of set of 8 Likert-type value items, ranked by respondents from 1 (strongly disagree) to 7 (strongly agree), which describes important aspects of human functioning in dimensions ranging from positive relationships, feelings of competence, to have meaning and a purpose in life.

The version of the Flourishing Scale used in this study was structured according to the original version with 8 value items $(\alpha=0.77)$. Examples of items on this scale: "I live a life with purpose and meaning" and "I am competent and able to do the activities that are important to me".

Still to ascertain psychological well-being, the Positive and Negative Experiences Scale was developed by Diener et al. (2009) and validated for the Portuguese Language by Caetano and Silva (2011). The original scale consists of a set of 12 items that assess general well-being in relation to life. In this study, it was also implemented with 12 items distributed in two factors, being ( 6 items) positive affects and (6 items) negative affects, which obtained Cronbach's alpha coefficients equal to 0.89 and 0.82 , respectively. The items are arranged on a five-point scale, ranging from 1 (very rarely or never) to 5 (very often), according to the feelings experienced by the unemployed in the last four weeks after losing their job.

It is worth mentioning that both the Flourishing Scale and the Positive and Negative Experiences Scale, indicated above, were measures chosen to assess the psychological well-being of the worker, commonly used in research. 


\section{Data analysis}

The collected data received statistical treatment using the IBM ${ }^{\circledR}$ SPSS ${ }^{\circledR}$ Statistics 21 software. An exploratory analysis of the items of the aforementioned scales was carried out to identify whether the scales were structured according to the original scales. Considering that the study variables were accessed by self-report and in a single moment, the common variance between the constructs could influence the relationships examined (Podsakoff, MacKenzie, Lee, \& Podsakoff, 2003). Therefore, in order to test the discriminant validity of the constructs, the Confirmatory Factor Analysis was performed using the Amos 21.0 software, to assess the overall fit of the model, and for the moderation analyses the Macro Process was used (Hayes, 2013).

Among the analyses performed and mentioned above, the calculated $\chi^{2}$, the ratio between the $\chi^{2}$ value and its degrees of freedom $-\chi^{2} / g l$ (Watkins, 1989), the Comparative Fit Index (CFI) (Bentler, 1988), the Goodness of Fit Index (GFI) (McDonald \& Ho, 2002) and the Root Mean Square Error of Approximation (RMSEA) (Browne \& Cudeck, 1993) stand out. The model is considered appropriate, when the value of $\chi^{2}$ is not significant, which indicates that there is no difference between the theoretical structure and the one underlying the data analyzed (Bentler \& Bonett, 1980), or if the $\chi^{2} / \mathrm{gl}$ ratio is lower than 3, or CFI and GFI present coefficients equal to or greater than 0.90 (Kline, 1994) or when RMSEA values are below 0.10 (Browne \& Cudeck, 1993). Confirmatory factor analyses were conducted to test the discriminant validity of the constructs and to verify whether the study measures benefit from the common variance of the method, following the recommendations of (Podsakoff et al., 2003), performing the model test with the inclusion of the latent variable.

Thus, the hypothetical model was first tested with the seven items that correspond to one factor (intrinsic values of work) that was compared with the model of four second order factors that correspond to: (a) intrinsic values of work, (b) positive and negative affects, (c) flourishing, and (d) unemployment time. Combined into a single factor (intrinsic value of labor), this model was tested and the following was obtained: $\left(\chi^{2} 356=921,115 ; p<0.017 ; \chi^{2} / g l=1.3 ; \mathrm{CFI}=0.56 ; \mathrm{GFI}=0.65 ; \mathrm{RMSEA}=0.014\right)$. The results indicate $\mathrm{a}$ slight increase in model adjustment.

After such adjustments to the model were made, the results of the confirmatory factor analysis offer empirical subsidies concerning the fit of the model, which includes the four second order factors: (a) intrinsic values, (b) positive and negative affects, (c) flourishing, and (d) time of unemployment. Subsequently, the observable variables whose estimate of the extracted variance was less than 0.50 were excluded, following the recommendations of Bagozzi and Yi (1988). The condition of the constructs is verified with empirically distinct measures and of good global fit, according to the values obtained $\left(\chi^{2} 356=267,681 ; p<0.017\right.$; $\left.\chi^{2} / g l=1.3 ; \mathrm{CFI}=0.93 ; \mathrm{GFI}=0.90 ; \mathrm{RMSEA}=0.056\right)$.

For the descriptive analysis and the correlation between the variables under study, the mean and standard deviation statistics and, further, the Pearson Correlation method were used, respectively (Table 1). To test the hypothesis presented, a set of regression models were conducted in the SPSS using the Process. The Process is a Macro developed by Hayes (2013) to test different models, such as moderation. Macro Model 1 was applied to test the moderation model with a moderator, and it was suggested that the relationship between the value of work (predictor variable) and Psychological Well-Being (PWB) (dependent variable) is moderated by the Time of Unemployment (TD) (Moderator), which better explains this relationship.

The research reported in the manuscript followed the Ethical Principles of the Resolution CNS $n^{\circ} 466$ about the Conduct of Research with Human Participants. The participants registered the consent after been informed about the research purposes, the risks involved in taking part of the research, the confidentiality and anonymity of the participation. The research protocol was approved by Pontifícia Universidade Católica de Goiás ethical board. The number of the approved document is $n^{\circ}$ 1.057.348. 
Table 1

Descriptive statistics and correlations of the study variables

\begin{tabular}{lccccccccc}
\hline Variables & $M$ & $D P$ & 1 & 2 & 3 & 4 & 5 & 6 & 7 \\
\hline 1. Age & 27.36 & 7.20 & & & & & & & \\
2. Gender & & & 0.04 & & & & & & \\
3. Education & 2.68 & 0.93 & $0.20^{* *}$ & 0.11 & & & & & \\
4. Unemploy-ment time & 7.26 & 8.05 & $0.30^{* *}$ & $0.12^{*}$ & -0.07 & & & & \\
5. Positive Affects & 3.58 & 0.93 & -0.07 & -0.04 & 0.04 & -0.06 & & & \\
6. Negative Affects & 2.29 & 0.88 & 0.04 & 0.12 & 0.08 & 0.02 & $-0.39^{* *}$ & & \\
7. Flourishing & 5.48 & 0.78 & 0.01 & -0.02 & 0.03 & 0.00 & $0.54^{* *}$ & $-0.32^{* *}$ & \\
8. Intrinsic Value of Work & 4.94 & 0.97 & 0.08 & 0.00 & $-0.19^{* *}$ & -0.07 & $0.14^{*}$ & -0.04 & $0.33^{* *}$ \\
\hline
\end{tabular}

Note: The information collected is represented by numerical indicators according to Table 1 of descriptive statistics that shows the measures of central tendency $\mathrm{M}=$ Mean and measures of dispersion, $\mathrm{SD}$ = Standard Deviation. The correlations demonstrates the magnitude of the relationship between two variables; the sign $\left(^{*}\right)$ corresponds to values with significant correlations. Being $0.20^{* *}$ and $0.30^{* *}$ a positive correlation between age, education and unemployment time; $0.12^{*}$ between gender and unemployment time; $-0.19^{* *}$ the negative correlation between education and intrinsic value of work; $-0.39^{* *}$ and $-0.32^{* *}$ negative correlations between negative and positive affects and vice versa; $0.54^{* *}, 0.14^{* *}$ positive correlations between positive affects, flourishing and intrinsic work values; $0.33^{* *}$ positive value between flowering and intrinsic work values. The values demonstrated received statistical treatment using the software IBM ${ }^{\circledR}$ SPSS ${ }^{\circledast}$ (version 21.0)

\section{Results}

The results of the studies performed demonstrate a significant correlation between age, education level and time of unemployment, with age being positively related to education level and time of unemployment $(r=0.20, p<0.01 ; r=0.30, p<0.01$; respectively). Despite the result, age was not assessed in this study; however, studies recognize the measure as one of the moderators that also influences unemployment perception, where the more the time goes by leading to maturity, the longer the duration of unemployment, due to the difficulty of relocating in the labor market (Ahn \& Hamilton, 2019; Startiene \& Remeikiene, 2015). The results of the relationships between age, education and time of unemployment confirm the values also found by Barros and Moreira (2015).

Education has a negative association with the meaning of work $(r=-0.19, p<0.01)$, as the data confirm that the longer the education, the lower the value of work and the lower the meaning it has in the life of a person. Correlations show that negative affects are negatively associated with positive affects and flourishing - here implemented as a measure of PWB $(r=-0.39, p<0.01 ; r=-0.32, p<0.01$, respectively) which supports the second hypothesis that unemployment can affect the psychological well-being of individuals, especially in the first 6 months.

Positive affects, in turn, are positively associated with flourishing and to the intrinsic value of work $(r=0.54, p<0.01 ; r=0.14, p<0.01$, respectively). They support the first hypothesis $(\mathrm{H} 1)$, that the positive perception of unemployment associated with the intrinsic value of work provides a better adaptation to the stressful moment, consequently, stabilization of harmful effects and the experience of well-being (Thill et al., 2019; Virkes et al., 2017).

Moderation analyses were performed using the Process 2.1 software, according to Hayes (2013), a technique that is based on the evaluation of the paths presented between the studied variables and provides the calculation of the significance of the interactive effects. As can be seen, this is a statistically significant model $\left(r=0.35, R^{2}=0.12 F(12.26), p<0.001\right)$ and this model was responsible for $12 \%$ of the variance of the time of unemployment over well-being.

The regression equations tested each path established in the hypotheses. The estimates presented are based on 5,000 bootstrap samples. The effects were estimated with corrected bias using 95\% Confidence Intervals $(\mathrm{Cl})$. In addition, each equation was controlled for age, gender, education and length of unemployment.

The result obtained empirically supports the Hypothesis $(\mathrm{H} 2)$ confirming that the period of unemployment negatively affects psychological well-being in the first few months ( $B=-0.51, p<0.001)$. The 
values demonstrate that there is a positive correlation between the intrinsic value of work and well-being $(B=0.011 p<0.001, C l=0.05120,3002)$ confirming $(\mathrm{H} 1)$, that the high perception of the value of work can help adapting unemployment and stabilizing the negative effects of the situation.

As noted, unemployment time negatively affects psychological well-being, but after a few months there is an improvement in these effects. The unemployment time, therefore, moderates the relationship between the intrinsic value of work and well-being, and this improvement effect can be seen in the face of Low TD (interaction $b=0.1868, t=3.11, p<0.005$ ) and High TD (interaction $b=0.3458, t=5.79, p<0.005$ ) which supports $(\mathrm{H} 3)$, that in the face of long unemployment time the relationship between well-being and the value of work is greater (Figure 1).

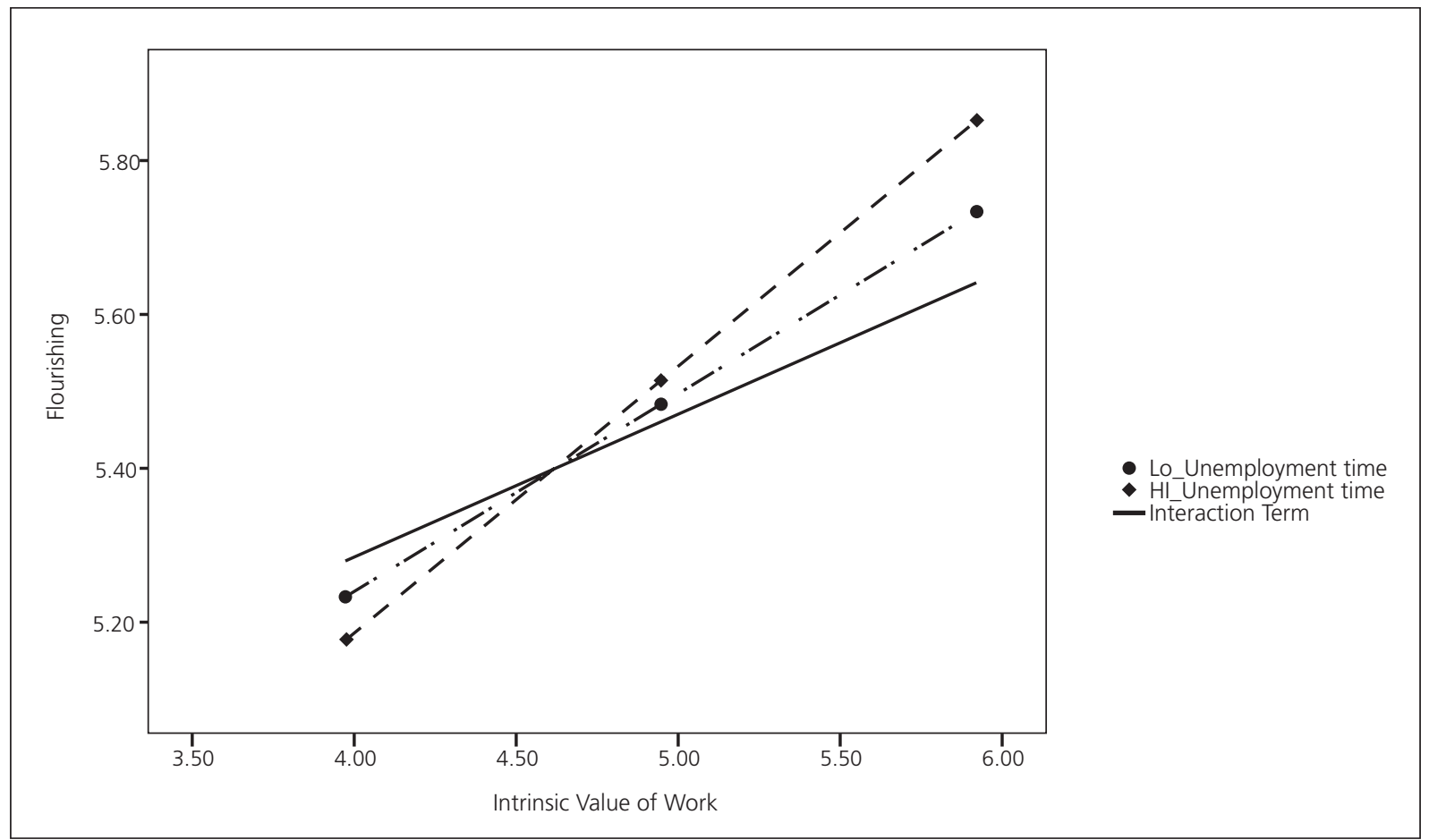

Figure 1. Interactional terms of intrinsic value at work and unemployment time on flourishing.

In addition, the results showed that the term of unemployment Time and Intrinsic value of work is significant $(B=0.011, p<0.005$ ), which enhances the $\mathrm{H} 3$ that unemployment Time acts as a moderator in the relationship between the intrinsic value of work and well-being, so that in the presence of extended unemployment this relationship is stronger, as the individual begins to mobilize internal and external resources to face the situation in a positive way; for this reason a decrease in negative effects is observed. Therefore, this moderation test indicates a considerable potential of the unemployment time in the relationship between work and well-being

\section{Discussion}

The aim of this investigation was to analyze the moderating power of unemployment time in the relationship between the intrinsic value of work and well-being, so that the longer the unemployment 
time, the greater this relationship will be. According to the results presented, unemployment is stressful in people's lives and, in fact, it can negatively affect the well-being of individuals. However, it is observed that this deterioration is more marked in the first months after job loss and, that, with the passage of time, there is a decrease in harmful effects (Fryer, 2015).

The values obtained for negative affects and flourishing, and positive affects follow the inverse logic of the relationship, and in the presence of positive affects and flourishing, the indicators of psychological well-being, are lower than the perception of negative affects. These results corroborate the findings of Barros and Moreira (2015), who state that the initial stages of unemployment are more degrading; however, over the days the state of torpor tends to stabilize.

In addition, as it is a multidetermined phenomenon, unemployment is potentially influenced by several factors, although it is understood as a harmful experience, the magnitude of its effects on well-being potentially depends on the interaction between socioeconomic stimuli, perceptions and individual self-concepts (Mousteri et al., 2018; Stam, Sieben, Verbakel, \& Graaf, 2015).

Thus, taken together, the theories suggest that the psychological consequences of unemployment depend on the extent in which unemployment interferes with the fulfillment of purposes related to specific social identities and, how central, is employment and the value of work in people's lives (Gagné et al., 2015; Thill et al., 2019).

The results demonstrated that the time of unemployment increases the relationship between the intrinsic value of work and well-being, which enhances the idea that coping with stressful situations is able to provide the stabilization of negative effects, leading to the emotional homeostasis of the individual (Virkes et al., 2017).

The moderation analysis, as established by Hayes (2013), demonstrated that the duration of unemployment associated with the value of work is a predictor of psychological well-being. This means that as the time of unemployment increases, the unemployed individuals have a stronger perception of the value of work and its importance as a source of emancipation, growth and development.

This perception creates an environment conducive to coping through hope and good expectations, including finding a new job, which enhances the meaning of a job and, consequently, increases the feeling of well-being (Hergenrather et al., 2015).

In this investigation, although the results demonstrate that there is no relationship between the moderating variable (unemployment time) and negative affects, which is why the moderation analysis occurred only for positive affects and flourishing, both measures of well-being in the investigated group present a pattern with respect to the reduction of negative aspects caused by unemployment.

It was observed that as time without work increases, the state of pain and torpor decreases, which allows the appearance of positive aspects such as motivation and feelings of excitement that provide well-being, with other factors being secured, such as social support, social security plans among other aspects already mentioned (Gagné et al., 2015; Hergenrather et al., 2015).

Such confirmation reinforces the assumptions that the unemployment situation is not adverse for all people. This is because unemployed individuals, despite facing a troubled moment, are not passive victims and, in general, they react to unemployment with various coping strategies in order to maintain their own psychological balance and protect themselves (Li et al., 2015; Mousteri et al., 2018; Nekoei \& Weber, 2017). Therefore, it is possible to normalize the negative effects, especially when unemployment is considered common in people's professional lives, and work is not the only source of happiness and well-being.

This study has limitations that must be considered. First of all, it is a cross-sectional study, whose variables were measured with a single instrument, at a single point in time, which prevents any inference of 
causality and generalization. Considering the fact that the investigation was carried out with self-reported data, these data may be benefiting from the common variance of the method; however, the explained variance of the method factor is in the average specified by Williams, Cote, and Buckley (1989); thus, the results represent important effects.

\section{Final Considerations}

This study was conducted with unemployed people in the city of Goiânia and its metropolitan region, Goiás state, and its main contribution is related to the importance of the value of work as a predictor of psychological well-being during unemployment spells.

What was found is that the time of unemployment can influence the perception of the value of work and the psychological well-being of individuals. These results are of great importance for the community in general, as it is understood that although unemployment is considered a stressful time that generates physical and emotional stress for the unemployed individuals, depending on their perception of the value of work, and their coping strategies and perspectives for the future, it is possible that their suffering is minimized or even stabilized over the months without work.

Another contribution refers to the test of the moderate model of unemployment time in the relationship between the value of work and psychological well-being. The results demonstrate that time can minimize the deleterious effects of unemployment, that is, as the months go by without work, the relationship between the intrinsic value of work and psychological well-being gets stronger. This is because the self-concept in relation to the value of work enables the experimentation of positive affects and good expectations, in relation to life itself; these factors mobilize coping of the demand and increase well-being.

The analysis of the results obtained in this study in comparison with previous studies demonstrates the need to develop investigations that cover different sample groups, which will allow us to observe the existence of a pattern of relationships between the value of work and the time of unemployment on the psychological well-being. In addition, future research should lead to longitudinal, experimental research designs or whose data collection is made from multiple sources or multiple points in time.

Another perceived limitation is that although the study demonstrated the importance and centrality that work signifies in people's lives, as it was conducted only with unemployed people, other factors may have failed to be considered. Therefore, it is suggested that in future investigations evaluation of the perspective of the value of work for other groups such as retirees, young university graduates and others be assessed.

However, it is hoped that these results can contribute to the benefit of the scientific community in general and encourage new research, in the continuous task of investigating what factors and circumstances lead some people, who, despite facing moments of extreme difficulty and limitation, as in the case of unemployment, are still capable, due to multiple factors, to continue to pursue their lives, conquering spaces and advancing their future.

Despite the results showing that the unemployed are endowed with the ability to reframe painful situations such as job loss, unemployment is still a phenomenon with different nuances, which unbalances and excludes many individuals.

\section{Contributors}

A. FIDELIS was responsible for conception, data analysis and interpretation, discussion of the results, review, and approval of the final version of the article. H. MENDONÇA participated to the whole process of this study development, including the conception of the research model, data analysis and final review. 


\section{References}

Ahn, H. J., \& Hamilton, J. D. (2019). Heterogeneity and unemployment dynamics. Journal of Business \& Economic Statistics, 38(3), 554569. https://doi.org/10.1080/07350015.2018.1530116

Barros, R. M., \& Moreira, A. S. (2015). Desemprego, autoestima e satisfação com a vida: estudo exploratório realizado em Portugal com beneficiários do Rendimento Social de Inserção. Revista Psicologia Organizações e Trabalho, 15(2), 146-156.

Bagozzi, R. P., \& Yi, Y. (1988). On the evaluation of structural equation models. Journal of the Academy of Marketing Science, 16(1), 74-94. https://doi.org/10.1007/bf02723327

Bentler, P. M. (1988). Comparative fit indexes in structural models. Psychological Bulletin, 107(2), 238. https://doi. org/10.1037/0033-2909.107.2.238

Bentler, P. M., \& Bonett, D. G. (1980). Significance tests and goodness of fit in the analysis of covariance structures. Psychological Bulletin, 88(3), 588-606. https://doi.org/10.1037/0033-2909.88.3.588

Black, S. E., Devereux, P. J., \& Salvanes, K. G. (2015). Losing heart? The effect of job displacement on health. ILR Review, 68(4), 833-861. https://doi.org/10.1177/0019793915586381

Browne, M. W., \& Cudeck, R. (1993). Alternative ways of assessing model fit. Sociological Methods and Research, 21(2), 230-258. https://doi.org/10.1177/0049124192021002005

Caetano, A., \& Silva, A. S. (2011). Bem-estar subjectivo e saúde no trabalho. In M. P. Lopes, P. J. Palma, R. B. Ribeiro, \& M. P. Cunha (Orgs.). Psicologia aplicada (pp.337-362). Lisboa: RH Editora.

Dejours, C., Dessors, D., \& Desriaux, F. (1993). Por um trabalho, fator de equilíbrio. Revista de Administração de Empresas, 33(3), 98-104. https://doi.org/10.1590/s0034-75901993000300009

Diener, E., Wirtz, D., Tov, W., Kim-Prieto, C., Choi, D., Oishi, S., \& Biswas-Diener, R. (2009). New well-being measures: short scales to assess flourishing and positive and negative feelings. Social Indicators Research, 97(2), 143-156. https:// doi.org/10.1007/s11205-009-9493-y

Duygan-Bump, B., Levkov, A., \& Montoriol-Garriga, J. (2015). Financing constraints and unemployment: evidence from the Great Recession. Journal of Monetary Economics, 75, 89-105. https://doi.org/10.1016/j.jmoneco.2014.12.011

Farber, H. S., \& Valletta, R. G. (2015). Do extended unemployment benefits lengthen unemployment spells Evidence from recent cycles in the US labor market. Journal of Human Resources, 50(4), 873-909. https://doi.org/10.3368/jhr.50.4.873

Feather, N. T. (1990). The psychological impact of unemployment. New York: Springer. https://doi.org/10.1007/978-14612-3250-6

Ferreira, J. A., Reitzle, M., Lee, B., Freitas, R. A., Santos, E. R., Alcoforado, L., \& Vondracek, F. W. (2015). Configurations of unemployment, reemployment, and psychological well-being: a longitudinal study of unemployed individuals in Portugal. Journal of Vocational Behavior, 91, 54-64. https://doi.org/10.1016/j.jvb.2015.09.004

Fryer, D. (2015). Unemployment and Mental Health: Hazards and Challenges of Psychology in the Community. In K. Isaksson, C. Hogstedt, C. Eriksson, \& T. Theorell (Eds.). Health Effects of the New Labour Market (pp.11-23). Boston: Springer. https://doi.org/10.1007/0-306-47181-7_3

Gagné, M., Forest, J., Vansteenkiste, M., Crevier-Braud, L., van den Broeck, A., Aspeli, A. K., ... \& Halvari, H. (2015). The Multidimensional Work Motivation Scale: validation evidence in seven languages and nine countries. European Journal of Work and Organizational Psychology, 24(2), 178-196. https://doi.org/10.1080/1359432x.2013.877892

Hayes, A. F. (2013). Model templates for process for SPSS and SAS. New York: Guilford Publications.

Hergenrather, K. C., Zeglin, R. J., McGuire-Kuletz, M., \& Rhodes, S. D. (2015). Employment as a social determinant of health: a review of longitudinal studies exploring the relationship between employment status and mental health. Rehabilitation Research, Policy, and Education, 29(3), 2-26. https://doi.org/10.1891/2168-6653.29.3.261

Huffman, A. H., Culbertson, S. S., Wayment, H. A., \& Irving, L. H. (2015). Resource replacement and psychological well-being during unemployment: the role of family support. Journal of Vocational Behavior, 89, 74-82. https:// doi10.1016/j.jvb.2015.04.011

Junça-Silva, A., Caetano, A., \& Lopes, R. R. (2016). Daily uplifts, well-being and performance in organizational settings: the differential mediating roles of affect and work engagement. Journal of Happiness Studies, 18(2), 591-606. https:// doi.org/10.1007/s10902-016-9740-2

Kline, P. (1994). An easy guide to factor analysis. London: Routledge 
Landais, C. (2015). Assessing the welfare effects of unemployment benefits using the regression kink design. American Economic Journal: Economic Policy, 7(4), 243-278. https://doi.org/10.1257/pol.20130248

Li, Y., Wei, F., Ren, S., \& Di, Y. (2015). Locus of control, psychological empowerment and intrinsic motivation relation to performance. Journal of Managerial Psychology, 30(4), 422-438. https://doi.org/10.1108/jmp-10-2012-0318

Lundin, A., Falkstedt, D., Lundberg, I., \& Hemmingsson, T. (2014). Unemployment and coronary heart disease amongmiddle-agedmen in Sweden: 39 243men followed for 8 years. Occupational and Environmental Medicine, 71 , 183-188. http://doi.org/10.1136/oemed-2013-101721

Mendonça, H. Caetano, A., Ferreira, M. C., Félix, I., \& Junça, A., (2014). Florescimento no trabalho. In M. M. M. Siqueira (Org.), Novas medidas do comportamento organizacional: ferramentas de diagnóstico e de gestão. Porto Alegre: Artmed.

McDonald, R. P., \& Ho, M.-H. R. (2002). Principles and practice in reporting structural equation analyses. Psychological Methods, 7(1), 64-82. https://doi.org/10.1037/1082-989x.7.1.64

Mousteri, V., Daly, M., \& Delaney, L. (2018). The scarring effect of unemployment on psychological well-being across Europe. Social Science Research, 72, 146-169. https://doi.org/10.1016/j.ssresearch.2018.01.007

Nekoei, A., \& Weber, A. (2017). Does extending unemployment benefits improve job quality? American Economic Review, 107(2), 527-61. https://doi.org/10.1257/aer.20150528

Parker, P. D., Jerrim, J., \& Anders, J. (2016). What effect did the global financial crisis have upon youth wellbeing? Evidence from four Australian cohorts. Developmental Psychology, 52(4), 640-651. http://dx.doi.org/10.1037/dev0000092

Pignault, A., \& Houssemand, C. (2017). Normalizing unemployment: a new way to cope with unemployment? Basic and Applied Social Psychology, 39(6), 372-386. https://doi.org/10.1080/01973533.2017.1373646

Pignault, A., \& Houssemand, C. (2018). An alternative relationship to unemployment: conceptualizing unemployment normalization. Review of General Psychology, 22(3), 355-366. https://doi.org/10.1037/gpr0000148

Podsakoff, P. M., MacKenzie, S. B., Lee, J. Y., \& Podsakoff, N. P. (2003). Common method biases in behavioral research: a critical review of the literature and recommended remedies. Journal of Applied Psychology, 88(5), 879. https://doi. org/10.1037/0021-9010.88.5.879

Popovici, I., \& French, M. T. (2013). Does unemployment lead to greater alcohol consumption? Industrial Relations, 52(2), 444-466. http://dx.doi.org/10.1111/irel.12019

Sage, D. (2019). Unemployment, wellbeing and the power of the work ethic: implications for social policy. Critical Social Policy, 39(2), 205-228. https://doi.org/10.1177/0261018318780910

Schwartz, S. H. (1999). A theory of cultural values and some implications for work. Applied Psychology, 48(1), 23-47. https://doi.org/10.1111/j.1464-0597.1999.tb00047.x

Stam, K., Sieben, I., Verbakel, E., \& Graaf, P. M. (2015). Employment status and subjective well-being: the role of the social norm to work. Work, Employment and Society, 30(2), 309-333. http://dx.doi.org/10.1177/0950017014564602

Startiene, G., \& Remeikiene, R. (2015). The influence of demographical factors on the interaction between entrepreneurship and unemployment. Engineering Economics, 64(4), 75-95.

Su, R., Tay, L., \& Diener, E. (2014). The development and validation of the Comprehensive Inventory of Thriving (CIT) and the Brief Inventory of Thriving (BIT). Applied Psychology: Health and Well-Being, 6(3), 251-279. https://doi. org/10.1111/aphw.12027

Thill, S., Houssemand, C., \& Pignault, A. (2019). Unemployment normalization: its effect on mental health during various stages of unemployment. Psychological Reports, 122(5), 1600-1617. http://dx. doi.org/10.1177/0033294118794410

Trewick, N., \& Muller, J. (2014). Unemployment in military spouses: an examination of the latent and manifest benefits, quality of life, and psychological wellbeing. Australian Journal of Career Development, 23(2), 47-56. http://dx.doi. org/10.1177/1038416213520306

van den Broeck, A., Vansteenkiste, M., Lens, W., \& De Witte, H. (2010). Unemployed individuals' work values and job flexibility: an explanation from Expectancy-Value Theory and Self-Determination Theory. Applied Psychology, 59(2), 296-317. http://dx.doi.org/10.1111/j.1464-0597.2009.00391.x

Virkes, T., Maslić Seršić, D., \& Lopez-Zafra, E. (2017). Core Self-Evaluations and Individual Strategies of Coping with Unemployment among Displaced Spanish Workers. The Spanish Journal of Psychology, 20, e59. https://doi.org/10.1017/ sjp.2017.57

Wanberg, C. R., Kanfer, R., Hamann, D. J., \& Zhang, Z. (2016). Age and reemployment success after job loss: an integrative model and meta-analysis. Psychological Bulletin, 142(4), 400-426. https://doi.org/10.1037/bul0000019 
Watkins, D. (1989). The Role of confirmatory factor analysis in cross-cultural research. International Journal of Psychology, 24(6), 685-701. https://doi.org/10.1080/00207598908247839

Williams, L. J., Cote, J. A., \& Buckley, M. R. (1989). Lack of method variance in self-reported affect and perceptions at work: reality or artifact? Journal of Applied Psychology, 74(3), 462-468. https://doi.org/10.1037/0021-9010.74.3.462

Zhou, Y., Zou, M., Woods, S. A., \& Wu, C.-H. (2019). The restorative effect of work after unemployment: an intraindividual analysis of subjective well-being recovery through reemployment. Journal of Applied Psychology, 104(9), 1195-1206. https://doi.org/10.1037/apl0000393

Received: March 20, 2019

Final version: April 16, 2020

Approved: July 1, 2020 